\title{
PENERAPAN GROUP ART THERAPY BAGI ANAK-ANAK MASA PERTENGAHAN YANG MEMILIKI KECENDERUNGAN AGRESI VERBAL
}

\author{
Fidia Hanan', Debora Basaria², Santy Yanuar $^{3}$ \\ ${ }^{1}$ Jurusan Psikologi, Universitas Tarumanagara Jakarta \\ Email: fidiahanan.asyst@gmail.com \\ ${ }^{2}$ Jurusan Psikologi, Universitas Tarumanagara Jakarta \\ Email: deborabasariayulianti@gmail.com \\ ${ }^{3}$ Jurusan Psikologi, Universitas Tarumanagara Jakarta \\ Email: Santyyp@gmail.com
}

\begin{abstract}
ABSTRAK
Rumah singgah $\mathrm{X}$ adalah sebuah rumah singgah yang berada di lokasi perkampungan nelayan Cilincing, Tanjung Priok, Jakarta Utara yang memberikan bimbingan belajar gratis bagi anak-anak dari kalangan masyarakat pra sejahtera dimana sebagian besar pekerjaan orangtuanya seperti nelayan, pemulung, pengemis, sopir, pekerja kasar/buruh dan keluarga dengan pendapatan minim. Berbagai kesulitan hidup dan lingkungan yang kurang kondusif di rumah singgah X menimbulkan dampak beraneka ragam dalam diri anak-anak tersebut, salah satunya adalah munculnya perilaku agresi verbal. Oleh sebab itu, group art therapy diterapkan untuk mengurangi agresi verbal dari 5 orang anak di rumah singgah X. Penelitian ini menggunakan mixed method one group pre-test, post-test design dengan menggunakan alat ukur agresivitas, tes CFIT, draw a person test dan wawancara semi terstruktur yang dianalisa untuk mengetahui perbandingan hasil sebelum dan sesudah pemberian intervensi. Setelah intervensi, berdasarkan hasil observasi, draw a person test dan skala agresivitas menunjukkan adanya penurunan skor agresi verbal pada kelima partisipan. Hal ini menunjukkan bahwa group art therapy cukup efektif untuk mengurangi kecenderungan agresi verbal pada kelima anak di rumah singgah X.
\end{abstract}

Kata kunci : Anak-anak masa pertengahan, Group Art Therapy, Rumah Singgah, Agresi Verbal

\section{PENDAHULUAN}

\section{Latar Belakang}

Anak-anak usia sekolah dasar atau periode middle childhood, umumnya berada dalam proses perkembangan yang berlangsung dengan cepat dalam aspek fisik, emosional, intelektual dan sosial. Dalam tahap perkembangan tersebut, tak jarang anak mengalami hambatan atau bahkan melakukan perilaku yang keliru yang dapat merugikan mereka, baik untuk dirinya sendiri maupun orang lain. Perilaku yang dicerminkan dapat berupa perilaku yang positif dan perilaku yang negatif, salah satunya yaitu berupa perilaku kenakalan. Kenakalan pada anak dimaknai sebagai suatu bentuk perilaku yang tidak sesuai dengan norma-norma yang hidup di tengah masyarakat. Pada umumnya, kenakalan merupakan produk konstitusi defektif dari mental dan emosi, yaitu mental dan emosi anak yang belum matang (labil) dan rusak (defektif) sebagai akibat proses pengondisian oleh lingkungan yang buruk (Kartono, 2007). 
Rumah singgah $\mathrm{X}$ adalah sebuah rumah singgah yang berada dilokasi perkampungan nelayan Cilincing, Tanjung Priok, Jakarta Utara yang memiliki tujuan sebagai wadah bimbingan belajar gratis bagi anak-anak dari kalangan masyarakat pra sejahtera dimana sebagian besar pekerjaan orangtuanya seperti nelayan, pemulung, pengemis, sopir, pekerja kasar/buruh, keluarga dengan pendapatan minim dan sebagainya. Lembaga ini didirikan untuk mengurangi tingkat putus sekolah pada anak-anak hingga remaja karena ketiadaan biaya. Jumlah anak didik sampai saat ini yang ikut les di rumah singgah X, berjumlah 200 lebih anak, dengan rentang usia 4-17 tahun. Berbagai kesulitan hidup yang dirasakan oleh anak-anak tersebut memiliki dampak beraneka ragam dalam diri mereka, salah satunya adalah munculnya perilaku agresivitas.

Menurut Buss dan Perry (1992), terdapat dua dimensi yang dapat digunakan untuk melihat perilaku agresif secara umum, yaitu: (1) Agresi fisik yang merupakan kecenderungan anak melakukan serangan fisik sebagai ungkapan ekspresi kemarahan seperti; memukul, menggigit, mencubit, menendang, menginjak, melempari orang dengan benda, dan sebagainya. (2) Agresi verbal yaitu kecenderungan untuk menyerang orang lain secara verbal seperti dengan mengucapkan kata-kata hinaan atau mengejek, memaki dengan kata-kata kotor, melecehkan, mengancam, membentak orang yang lebih tua, atau bahkan memerintah orang lain seenaknya saja. Perilaku agresif secara psikologis cenderung menyerang kepada sesuatu yang dipandang sebagai hal yang mengecewakan, menghalangi atau menghambat. Perilaku ini terjadi pada masa perkembangan, karena pada masa inilah seorang anak sudah mulai merasa ingin mengetahui dan ingin melakukan sesuatu yang dia inginkan walaupun tanpa dia sadari sesuatu yang dia lakukan itu dapat berdampak negatif pada dirinya sendiri ataupun pada orang lain (Hurlock, 1987).

Perilaku agresif anak muncul manakala anak merasakan adanya ancaman, marah, gusar, atau frustrasi. Perilaku agresif sesungguhnya merupakan reaksi normal pada anak-anak yang masih kecil. Anak-anak secara naluriah akan memunculkan perilaku ini ketika mereka merasa tidak nyaman, ketika mereka ingin melindungi diri mereka atau ketika mereka ingin mencapai suatu tujuan tertentu namun tidak mengetahui bagaimana cara yang lebih baik untuk meraihnya. Selain itu, perilaku agresif juga merupakan cara khas anak kecil untuk menunjukkan kepada orang lain bahwa mereka tidak suka pada apa yang dilakukan orang lain terhadap mereka. Akan tetapi, seiring dengan bertambahnya usia mereka, anak-anak seharusnya menjadi semakin mampu menggunakan cara-cara yang lebih tepat untuk meraih tujuannya, sehingga tidak perlu bertindak dengan cara yang agresif. Perilaku agresif menjadi bagian dari tahapan perkembangan mereka dan sering kali menimbulkan masalah, baik itu di rumah, sekolah ataupun dalam suatu kelembagaan yang mana disuatu tempat tersebut dia dapat berinteraksi terutama dengan orang lain. Diharapkan setelah melewati usia 7 tahun, anak sudah lebih dapat mengendalikan dirinya untuk tidak menyelesaikan masalah dengan perilaku agresif.

Perilaku agresi dipengaruhi oleh beberapa faktor. Menurut Shechtman (2009) terdapat empat faktor yang menyebabkan perilaku agresi. Faktor yang pertama adalah faktor biologis, genetik, dan temperamen. Faktor kedua adalah keluarga, orang tua yang menggunakan kekerasan untuk mendidik anak akan menghasilkan anak yang juga bertindak agresi. Faktor ketiga adalah pengaruh sosial, termasuk sistem sosial secara mikro dan makro. Pada level makro terdapat aturan-aturan dan norma budaya dari lingkungan sekitar. Misalkan pada budaya yang menuntut anak untuk lakilaki untuk lebih agresif. Sedangkan level mikro meliputi teman-teman dan lingkungan di sekolah. Anak belajar norma yang terdapat di dalam kelasnya, anak bertindak agar dirinya dapat diterima 
oleh teman-temannya. Ketika norma yang ada mendukung perilaku agresi, maka anak yang tadinya kurang agresif cenderung menjadi lebih agresif. Faktor yang keempat adalah kesulitan belajar. Anak yang mengalami kesulitan belajar cenderung memiliki kesulitan sosial, kesepian dan kesulitan dalam memproses informasi yang ada dan dalam mengontrol perilaku. Hal ini membuat adanya kecenderungan yang lebih tinggi untuk anak menjadi lebih agresif (Shechtman, 2009).

Lindwood (2006) mengatakan bahwa agresi pada anak berhubungan dengan keluarga yang berasal dari status ekonomi menengah ke bawah, kriminalitas, atau adanya gangguan psikologis. Wirawan (2009) menambahkan perilaku agresif berasal dari masalah lingkungan, personal, situasional, media massa, dan adanya kekerasan dalam rumah tangga. Agresi pada anak dapat terbentuk karena setiap hari anak sering melihat dan menyaksikan kekerasan dalam rumah tangga baik secara langsung atau tidak langsung yang dilakukan ayah terhadap ibu dan anaknya. Sebagaimana penelitian Hartini (2009) bahwa anak mengadopsi perilaku agresinya dari hasil belajar melalui pengamatan anak kepada orang tua serta anak dapat meniru semua tingkah laku orang tua yang didapatnya dari kekerasan tersebut.

Agresi pada anak juga dapat terjadi akibat pengaruh media massa yang berisi kekerasan (tayangan film). Demikian juga menurut Santrock (2002) dan Kirsh (2006) bahwa bahwa tayangan kekerasan di televisi yang terus menerus ditonton oleh anak-anak menyebabkan meningkatnya agresi pada anak-anak. Pada usia sekolah, perkembangan kognitif anak menyebabkan ia mampu melakukan fantasi. Isi fantasi banyak dipengaruhi oleh tontonan yang disaksikan oleh anak. Melalui tontonan tersebut, anak-anak mengetahui tokoh jahat dan tokoh baik sehingga timbul keinginan untuk berperilaku seperti tokoh-tokoh yang mereka kagumi. Penelitian Khumas, et al., (1997) menemukan bahwa ada hubungan antara fantasi agresi dan perilaku agresi pada anak-anak. Yayasan Kesejahteraan Anak Indonesia (YKAI) dalam Mulyana dan Ibrahim (1997) melakukan penelitian mengenai program acara di televisi Indonesia dimana persentase acara televisi yang ditujukan bagi anak relatif kecil.

Agresivitas yang tinggi dapat menjadi salah satu masalah psikologis yang membutuhkan penanganan melalui proses terapi, salah satunya adalah art therapy. Dalam hal ini, art therapy merupakan proses terapeutik yang menggunakan media seni sebagai asesmen dan intervensi. Penggunaan aktivitas seni sebagai terapi didasarkan pada asumsi bahwa gambar merupakan bentuk komunikasi dimana jarang dilakukan resistensi oleh anak, dan memberi anak cara baru untuk mengekspresikan pikiran dan perasaannya (Malchoidi, 2003).

Selain itu, Ballou (dalam Mukhtar, et al., 2006) menyatakan bahwa pada anak yang mengalami gangguan perilaku, aktivitas seni dapat membantu untuk menyalurkan dorongan agresif dengan cara yang lebih dapat diterima masyarakat serta dapat membantu ego untuk mengintegrasikan dan mengatur perasaan-perasaan dan impuls-impuls yang berkonflik dalam suatu bentuk estesis yang memberikan kepuasan. Seni adalah kegiatan yang dapat dilakukan dengan rileks dan menyenangkan dalam mengeskpresikan perasaan, pikiran, kreativitas, dan keunikan. Seni merupakan jalan keluar untuk mengekspresikan pikiran dan perasaan yang positif dan negatif tentang diri sendiri, keluarga, dan dunia. Ketika imajinasi kreatif yang dibuat dinilai oleh orang lain, perasaan menghargai diri akan berkembang (Djiwandono, 2005). Berdasarkan penelitian yang dilakukan oleh Wallin dan Duur (dalam Mukhtar, et al., 2006) diketahui bahwa art therapy dapat meningkatkan kemampuan belajar sosial dan emosional pada anak dan dapat mengurangi 
kecenderungan agresivitas pada anak. Oleh karena itu maka art therapy dirasa merupakan terapi yang tepat untuk membantu mengurangi kecenderungan agresivitas pada anak sehingga anak-anak yang mengalami agresivitas dapat menampilkan perilaku yang lebih positif dalam kehidupan sehari-hari.

\section{Rumusan Masalah}

Apakah group Art Therapy dapat mengurangi agresi verbal yang terjadi pada anak-anak masa pertengahan di rumah singgah $\mathrm{X}$ ?

\section{Tujuan Penelitian}

Terapi kelompok bertujuan untuk menurunkan kecenderungan agresi verbal anak-anak tersebut sehingga dapat menampilkan perilaku yang lebih positif dalam kehidupan sehari-hari.

\section{METODE PENELITIAN \\ Partisipan Penelitian}

Karakteristik partisipan yaitu: anak-anak di rumah singgah $\mathrm{X}$, berusia 7-12 tahun, memiliki keluhan agresi verbal.

\section{Desain Penelitian}

Desain penelitian yang digunakan dalam penelitian ini adalah metode penelitian secara kualitatif melalui cognitive debriefing yaitu dengan dilakukan wawancara dengan guru-guru. Penelitian ini juga menggunakan pre-test dan post-test sebagai analisa untuk menentukan kriteria partisipan dan mengetahui perbandingan hasil sebelum dan sesudah pemberian intervensi.

\section{Lokasi Penelitian}

Lokasi penelitian dilakukan di salah satu ruangan kelas yang disediakan rumah singgah X.

\section{Instrumen Penelitian}

Peralatan yang digunakan adalah lembar informed consent, alat ukur CFIT, alat ukur agresivitas, alat-alat lukis (kertas gambar A3, pensil, penghapus, tissue, crayon, cat warna dan kuas), clay, karet dan gunting.

\section{Pengukuran}

Alat ukur yang digunakan adalah tes grafis (Draw A Man), CFIT (Culture Fair Intelligence Test) Skala 3 serta skala perilaku agresivitas (Kristianto, A., 2009). Dalam pengukuran agresivitas skala ini dapat dilihat bahwa semakin tinggi skor yang diperoleh anak maka akan semakin tinggi perilaku agresifnya. Adapun hasil estimasi realibilitas alat ukur ini adalah Alpa Cronbach sebesar 0,940. Skala ini dapat digunakan untuk anak-anak middle childhood dengan tiga pilihan jawaban. Adapun rentang penilaian skala adalah sebagai berikut: Sering (1), Kadang-kadang (2) dan Tidak Pernah (3).

\section{Prosedur Penelitian}

Dalam menentukan kesamaan kelompok menggunakan data yang diperoleh dari rumah singgah $\mathrm{X}$ yaitu data mengenai daftar anak-anak yang mengikuti kelas les di pagi hari. Kemudian, peneliti memberikan tes DAM dan CFIT untuk mencari anak-anak yang memiliki indikasi agresi verbal. Sebelum terapi dijalankan, dilakukan pre-test dengan mengisi pernyataan yang terdapat pada 
kuesioner agresivitas, dengan skala 1-3, dimana 1 adalah sering sampai dengan 3 tidak pernah, Selanjutnya group art therapy dilakukan. Setiap sesi, partisipan harus mengikuti kegiatan kesenian yang bertujuan untuk menurunkan kecenderungan agresi verbal pada anak. Setelah itu, dilakukan post-test dengan menggunakan tes DAM kembali serta pengisian kuesioner agresivitas, dengan skala 1-3, dimana 1 adalah sering sampai dengan 3 tidak pernah.

\section{Pelaksanaan Penelitian}

Intervensi yang digunakan dalam kelompok ini menggunakan pendekatan art group therapy. Sesi akan dilakukan sebanyak 6 sesi yang dilakukan sebanyak tiga kali dalam satu minggu. Menurut Tyndall-Lind dan Landreth (2001), pada umumnya teknik terapi berlangsung antara 5-21 sesi, yang dapat berlangsung selama satu atau 2 tahun, namun untuk sesi singkat, biasanya dapat menggunakan 6-12 sesi. Pada art group therapy, partisipan diberikan kebebasan bergerak dan beraktivitas, anggota kelompok dapat memilih untuk mengobservasi atau berpartisipasi, berbicara atau berdiam diri, ingin melakukan sendiri atau dengan orang lain, berelasi aktif dengan orang lain atau berjarak dengan orang lain (Rubin, 2005).

Ketika anak mulai berelasi satu dengan yang lain, mereka terstimulasi, mendapatkan ide, menunjukkan usaha, membantu satu sama lain, dan terkadang memutuskan secara spontan untuk bekerja sama dalam tugas gabungan (Rubin, 2005). Pada beberapa kelompok, dapat berfokus pada topik atau masalah tertentu, terutama untuk ruang lingkup yang singkat dan terbatas. Aktivitas kelompok sebaiknya mengarah kepada tema utama yang dibutuhkan (Cohn dalam Rubin, 2005).

Tahapan yang akan dilakukan pada saat terapi menurut Landgarten (1981) adalah (a) perkenalan dan warm-up, yaitu dengan membuat karya seni bebas, tahap ini juga dapat menjadi aktivitas untuk menyesuaikan diri satu sama lain dalam lingkungan dan orang-orang yang baru, saling mengenal lebih dalam satu sama lain, (b) recalling event, mencoba membuka kembali ingatan tentang kejadian yang telah dialaminya, kemudian mengungkapkan perasaan terhadap kejadian tersebut; (c) emotional expression and issues, mencoba mengungkapkan emosi-emosi yang selama ini terpendam dalam diri Subyek, seperti kecemasan, ketakutan, kesedihan, kemarahan dan lain-lain; (d) restitution, menyadari permasalahan dan kenyataan yang terjadi, mencari jalan keluar untuk mengatasi permasalahan tersebut; (e) termination, penghentian terapi.

\section{HASIL INTERVENSI}

Pada sesi 1, intervensi dilaksanakan pada tanggal 6 November 2017 bertempat di ruang kelas yang telah disediakan pihak rumah singgah. Intervensi berjalan selama dua jam. Semua peserta memperkenalkan diri lalu membicarakan mengenai peraturan yang harus disepakati bersama. B terlihat yang paling bersemangat untuk menyuarakan pendapatnya. Saat diminta untuk menandatangani kontrak, kelima subyek langsung berebut spidol sesuai dengan warna yang disukai. Terlihat $\mathrm{P}$ dan $\mathrm{N}$ yang langsung berebut spidol merah. Ketika spidol merah didapatkan terlebih dahulu oleh $\mathrm{P}, \mathrm{N}$ tampak kesal dan cemberut sehingga harus diingatkan oleh peneliti jika masih banyak warna spidol lain yang bisa digunakan. Kemudian para peserta menuliskan harapannya masing-masing. Setelah menulis harapan, semua peserta mengisi kuesioner agresivitas dan menggambar bebas. Sebelum mulai menggambar, B tampak berinisiatif untuk mengambilkan minuman untuk teman-temannya. Saat mulai menggambar, $\mathrm{N}$ tidak langsung menggambar, melainkan hanya berdiam diri dan mengobservasi teman-temannya. $\mathrm{N}$ beberapa kali terlihat kebingungan. Sehingga saat teman-temannya sudah mulai setengah selesai, $\mathrm{N}$ baru mulai untuk 
mengerjakannya. L beberapa kali mengajak $\mathrm{N}$ untuk berbicara dan $\mathrm{N}$ meminta $\mathrm{L}$ untuk menggambarkan tugasnya. Sedangkan $\mathrm{P}$ bertengkar dengan $\mathrm{R}$ karena berebut spidol berwarna pink dan $\mathrm{P}$ mengeluarkan kata kasar dan $\mathrm{R}$ mengadu. Ketika ditegur, akhirnya $\mathrm{P}$ dan $\mathrm{R}$ mau bergantian menggunakan spidol. Pada tugas kali ini terlihat jika B yang menyelesaikan tugasnya pertama kali kemudian R. Setelah semua selesai, subyek diminta untuk bercerita satu per satu, dan B, P dan L saling berebutan untuk bercerita pertama. Ketika ada satu subyek bercerita, teman-teman yang lain cenderung sibuk dengan aktivitasnya masing-masing, terlebih pada subyek $\mathrm{N}$ dan $\mathrm{R}$. Peneliti harus berulang kali mengingatkan agar kedua subyek mau saling menghargai, subyek akhirnya mau mendengarkan. Kelima partisipan tampak kooperatif mengikuti kegiatan.

Sesi 2 dilaksanakan pada tanggal 11 November 2017. Pada sesi ini, saat diberikan pertanyaan mengenai rasa marah, peserta kemudian menyebutkan rasa marah yang mereka ketahui. Kemudian peserta diminta untuk untuk membuat list mengenai hal apa saja yang membuat mereka marah.

Tabel 1. Stimulus Agresi

\begin{tabular}{|c|c|c|}
\hline Nama & Pemicu Agresi & Reaksi Agresi \\
\hline $\mathbf{L S}$ & $\begin{array}{l}\text { Ketika tidak dipinjamkan barang } \\
\text { yang diinginkan, berebut makanan, } \\
\text { diejek oleh teman }\end{array}$ & $\begin{array}{l}\text { Memukul, menendang, menjambak, } \\
\text { berkata kasar }\end{array}$ \\
\hline NR & $\begin{array}{l}\text { Ketika tidak dipinjamkan barang } \\
\text { yang diinginkan dan keinginannya } \\
\text { tidak dipenuhi }\end{array}$ & $\begin{array}{l}\text { Memukul, menendang, menjambak, } \\
\text { berkata kasar, merebut kembali }\end{array}$ \\
\hline $\mathbf{R Y}$ & $\begin{array}{l}\text { Ketika tidak dipinjamkan barang } \\
\text { yang diinginkan, diganggu oleh } \\
\text { teman }\end{array}$ & Memukul, berkata kasar \\
\hline $\mathbf{P}$ & $\begin{array}{l}\text { Ketika tidak dipinjamkan barang } \\
\text { yang diinginkan }\end{array}$ & $\begin{array}{l}\text { Menjambak, berkata kasar, merebut } \\
\text { kembali }\end{array}$ \\
\hline MB & $\begin{array}{l}\text { Ketika tidak dipinjamkan barang } \\
\text { yang diinginkan, diganggu oleh } \\
\text { teman }\end{array}$ & Memukul, berkata kasar \\
\hline
\end{tabular}

Setelah itu semua peserta diminta untuk menggambarkan rasa marah/emosi negatif tersebut secara bebas. Saat menggambar, beberapa peserta saling mengomentari satu sama lain dengan ejekanejekan dan saling tertawa. Seperti L yang meledek gambar B sehingga semua anggota kelompok tertawa bersama. Setelah itu P merasa kesal karena catnya diambil oleh L dan L akhirnya mengejek $\mathrm{P}$ pelit karena tidak meminjamkan cat yang diminta. Peneliti terus mengingatkan peraturan yang telah disepakati bersama. Namun disini terlihat bahwa kelima subyek mau menaati peraturan yang telah disepakati bersama, dimana apabila masing-masing subyek melanggar, dengan kesadaran dirinya mereka melakukan konsekuensi yang telah ditentukan. Misalnya subyek lainnya akan menertawakan dan menasehati untuk tidak melakukan pelanggaran lagi sehingga $\mathrm{P}$ dan L segera meminta maaf. Saat mengerjakan tugas, tampak bahwa $\mathrm{R}$ berkali-kali berkata tidak bisa menggambar dan ia hanya memperhatikan kertas dalam waktu cukup lama sehingga harus berkalikali dimotivasi. B tampak fokus mengerjakan dengan menggunakan warna merah yang dominan untuk menunjukkan ekspresi amarahnya. Sedangkan N tampak fokus mengerjakan gambarnya 
dengan dominan menggunakan warna-warna gelap dan selesai lebih awal. Ketika L mengejek gambar $\mathrm{N}$ jelek, $\mathrm{N}$ membalas ejekan tersebut.

Setelah itu, seluruh partisipan diajak melakukan relaksasi dengan meminta seluruh partisipan untuk membayangkan rasa marah dan meminta mereka membuang emosi negatifnya melalui media kertas. Saat sesi ini berlangsung, tampak jika subyek B dan P terlihat sangat emosi dan mendengus kesal saat diminta untuk membuang emosi negatifnya. Kemudian mereka berdua merobek-robek dan mencabik-cabik kertas yang diberikan dan melemparkan sobekan kertas tersebut ke udara. Sedangkan pada subyek R, N dan L, mereka bertiga menyobek-nyobek kertas sambil tersenyum sehingga harus diingatkan mereka supaya kembali fokus. Setelah sesi selesai, seluruh anggota diminta untuk menceritakan bagaimana perasaan mereka. B menjadi orang yang pertama merobek kertas dan menceritakan bagaimana perasaannya gambarnya. Setelah itu dilanjutkan dengan P, R, N dan L. Pada dasarnya mereka mampu mengungkapkan perasaan marah mereka dan melampiaskannya kepada kertas tersebut, namun B dan P memiliki kosa kata yang lebih baik untuk mengungkapkan bagaimana perasaannya.

Sesi 3 dilaksanakan pada tanggal 13 November 2017. Pada sesi ini peneliti mengingatkan seluruh subyek mengenai list apa saja yang membuat mereka merasa sangat marah yang telah mereka buat pada sesi sebelumnya. Kemudian peneliti meminta semua subyek untuk membuat gambar mengenai hal-hal positif apa saja yang bisa dilakukan untuk mencegah emosi negatif tersebut secara bebas.Saat kegiatan dimulai, L tampak mengerjakan tugas sambil berbicara dan berkata kasar ketika diganggu. Hal ini menunjukkan L masih menunjukkan perilaku mengganggu teman dan mencari perhatian. $\mathrm{N}$ menampilkan perilaku jahil dan mengejek hasil karya temannya. Hal ini menunjukkan bahwa $\mathrm{N}$ belum memiliki rasa menghargai kepada teman. Sedangkan $\mathrm{R}$ tampak membutuhkan waktu lama untuk menyelesaikan tugas yang diberikan dan memiliki kebiasaan berebut alat tulis. Setelah berbuat salah, R meminta maaf. Hal ini menunjukkan bahwa R sudah memiliki kontrol diri dan menyadari kesalahannya. $\mathrm{P}$ marah karena spidolnya direbut dan mengerjakan tugas sambil menggerutu namun menerima permintaan maaf R. Hal ini menunjukkan jika P sudah memiliki kontrol diri dan bersikap dewasa untuk memaafkan kesalahan temannya. Terakhir, B tampak fokus dan antusias dalam menyelesaikan tugasnya sehingga selesai terlebih dahulu. B juga memiliki inisiatif untuk membersihkan peralatan. Ketika berbuat salah ia akan berusaha memperbaiki kesalahannya. Hal ini menunjukkan bahwa B mengikuti peraturan yang ditetapkan dan sudah memiliki kesadaran untuk memperbaiki kesalahan.

Sesi 4 dilaksanakan pada tanggal 17 November 2017. Pada sesi kali ini, kelima peserta diminta untuk memikirkan dan memilih tokoh yang disukai kemudian menggambarkan wajah tokoh favoritnya di selembar kertas karton kemudian mempersilahkan untuk mewarnainya dengan cat warna. Saat kegiatan ini berlangsung L tampak paling antusias dan memiliki banyak ide. L mengerjakan tugasnya sambil mengobrol dan bernyanyi hingga membuat teman-temannya terganggu. Namun L berinisiatif untuk membantu R yang kesulitan. Ketika memeragakan topeng yang dibuat, L tampak percaya diri. $\mathrm{N}$ marah pekerjaannya dicontek dan mengeluarkan kata kasar hingga akhirnya ditegur. $\mathrm{N}$ tidak mau menggunakan topengnya dan tidak ada inisiatif untuk memperbaikinya. Hal ini menunjukkan bahwa kontrol diri $\mathrm{N}$ masih kurang dan ia tidak memiliki insiatif. Sedangkan R berkali-kali mengeluh mengatakan tidak bisa, namun pada akhirnya ia dapat menyelesaikan topeng dengan fokus dan selesai tepat waktu setelah dibantu. $\mathrm{R}$ tampak malu saat menggunakan topeng. Hal ini menunjukkan jika kepercayaan dir R masih kurang sehingga masih 
memerlukan bantuan. Selanjutnya $\mathrm{P}$ tampak beberapa kali menyontek pekerjaan $\mathrm{N}$ sehingga membuat $\mathrm{N}$ marah. P menjadi orang terakhir yang menyelesaikan tugas karena sibuk bolak balik membersihkan cat. Ketika memeragakan topeng yang dibuat, $\mathrm{P}$ tampak percaya diri. Terakhir, B mengerjakan tugas sambil berdiri dan bolak balik sehingga harus diingatkan berkali-kali untuk kembali ke tempat duduk. B terlihat cemas ketika diberikan tugas yang ia tidak terlalu kuasai. Namun B senang ketika diberikan kesempatan untuk mengekspresikan dirinya dan tampak percaya diri.

Sesi 5 dilaksanakan pada tanggal 20 November 2017. Aktivitas pada hari itu adalah semua peserta harus bekerjasama membuat figur yang mereka inginkan dengan tema "taman bermain". Pada saat sesi berlangsung, kelima subyek menunjukkan kekompakkan, mau saling berbagi dan membantu. Setelah potongan-potongan besar clay sudah dibagi, semua subyek mulai berebutan berkata ingin membuat kreasi apa. Saat subyek lain sedang mengerjakan, $\mathrm{N}$ terlihat mengeluh beberapa kali dengan mengatakan jika ia tidak bisa membuat bentuk dan membutuhkan waktu yang lama untuk memulai pekerjaannya. Beberapa kali $\mathrm{N}$ terlihat kebingungan dan malah sibuk memperhatikan pekerjaan teman-teman yang lain sehingga L membantunya dengan memberikan ide bentuk apa yang harus ia buat. Sedangkan B banyak melakukan remasan kepada clay dan berpikir untuk beberapa saat lalu membentuk clay dengan hati-hati dan pelan hingga kemudian ia memutuskan untuk membuat ayunan. B tampak mengerjakannya dengan buru-buru sehingga hasil karyanya beberapa kali terlihat rusak. Sedangkan L, ia tampak fokus dan telaten ketika membuat bentuk boneka. Saat kaki bonekanya lepas, P tampak berinisiatif membantu L untuk memasangkannya kembali. Sedangkan R asyik membuat karya sambil mewarnai nya dengan cat warna. Setelah sudah selesai, beberapa kali $\mathrm{R}$ meminta bantuan kepada group leader untuk membantu menempelkan hasil karyanya diatas papan yang telah disediakan. Setelah peserta menyelesaikan hasil karya mereka, para peserta bergantian menceritakan satu-persatu mengenai ide yang tertuang dalam karya clay masing-masing. Para peserta tampak bercerita dengan antusias dan nampak bangga dengan figure yang mereka buat. Pada sesi ini, kelima subyek sudah lebih tenang saat mendengarkan temannya bercerita. Kelima subyek juga sudah lebih terbuka dan mau menceritakan pengalamannya. Komentar-komentar yang diberikan juga mengarah kepada hal yang positif dari karya temannya, dan mulai ada pujian-pujian untuk hasil karya temannya.

Sesi 6 dilaksanakan pada tanggal 25 November 2017. Pada sesi ini, kelima subyek diberikan tugas untuk menggambar kondisi diri mereka sesudah mengikuti kegiatan intervensi. L tampak paling bersemangat ketika diminta untuk menggambar. B menyelesaikan tugas menggambar paling cepat diantara yang lain walaupun hasil gambarnya agak berantakan. $\mathrm{R}$ terlihat fokus mengerjakan tugas yang diberikan. $\mathrm{P}$ mengerjakan tugas yang diberikan sambil tertawa dan menyelesaikan gambar sambil mengobrol dengan N. Gambar yang dibuat subyek cenderung bersifat positif, banyak emosi tersenyum atau digambarkan dengan warna yang lebih cerah. Setelah itu, peneliti meminta partisipan untuk mengisi kuesioner agresivitas dengan skala 1-3, dimana 1 adalah sering sampai dengan 3 tidak pernah. Kemudian, peneliti melakukan terminasi dan mengakhiri sesi 6. 
Tabel 2. Hasil Intervensi Penurunan Agresivitas Seluruh Subyek

\begin{tabular}{ccc}
\hline Inisial & Pretest & Posttest \\
\hline LS & 91 & 74 \\
\hline NR & 84 & 79 \\
RY & 87 & 84 \\
\hline P & 83 & 80 \\
\hline BA & 81 & 71 \\
\hline
\end{tabular}

Dari tabel di atas, setiap partisipan mengalami penurunan skor, sehingga dapat dikatakan bahwa intervensi berjalan dengan baik karena setiap partisipan sudah mampu untuk mengontrol diri dalam menurunkan kecenderungan agresi.

\section{KESIMPULAN}

Berdasarkan dari group art therapy yang telah dilaksanakan, dapat disimpulkan bahwa terapi ini dapat menurunkan kecenderungan agresi pada kelima subyek, walaupun belum menyeluruh. Penurunan kecenderungan agresi dapat terlihat dari hasil tes grafis DAM dan kuesioner agresivitas. Selain itu, dilengkapi juga dari hasil wawancara terhadap subyek setelah dilakukannya intervensi. Kelima subyek menunjukkan penurunan kecenderungan agresi, yaitu dengan digambarkannya leher, tangan, lalu serta rambut yang tajam dan dengan ekspresi tersenyum. Selain itu, intervensi kelompok ini juga bermanfaat terhadap relasi antara kelima subyek. Relasi antara kelima subyek mengalami perubahan ke arah yang lebih positif. Berdasarkan uraian di atas, dapat disimpulkan bahwa manfaat yang diperoleh dari kegiatan intervensi kelompok ini, antara lain subyek merasa lebih dapat melakukan kontrol diri, lebih mengusahakan kontak sosial secara positif dan mengurangi kecenderungan agresi verbal maupun fisik. Selain itu, intervensi kelompok ini juga bermanfaat bagi para peserta dengan adanya perubahan perilaku yang menjadi lebih positif seperti seperti pada L yang menjadi berusaha untuk mentaati peraturan yang berlaku dan memunculkan inisiatif untuk membantu temannya yang kesulitan serta lebih menghargai teman. B yang selalu memiliki inisiatif tinggi untuk membantu serta selalu menegur temannya saat bertengkar. P dan $\mathrm{N}$ yang dapat mengalah untuk meminta maaf dan memaafkan serta dapat menahan diri untuk tidak bertengkar dalam waktu yang lama, selanjutnya $\mathrm{R}$ yang sedikit demi sedikit menampilkan keinginannya untuk berubah ke arah yang lebih positif. Selain itu, para subyek juga mendapatkan manfaat dari bekerjasama dan saling membantu sehingga dapat membangun emosi positif diantara setiap subyek. Selain itu intervensi kelompok ini juga bermanfaat terhadap relasi antara kelima subjek tersebut mengalami perubahan ke arah yang positif. Mereka dapat lebih mudah diarahkan, kooperatif mengikuti sesi, saling menghargai dan toleran terhadap satu sama lain.

Berdasarkan uraian di atas, dapat disimpulkan bahwa manfaat yang diperoleh dari kegiatan intervensi kelompok ini adalah adanya penurunan agresivitas tehadap kelima subjek serta adanya keinginan untuk saling menaati peraturan, bersosialisasi, bermain dan bekerja sama pada seluruh subjek. Selanjutnya, ada pula feedback yang diperoleh dari peneliti dan dari teman-temannya, sehingga masing-masing subyek dapat memperoleh penilaian positif tentang dirinya dan dapat meningkatkan rasa kepercayaan diri bagi dirinya sendiri.

\section{Diskusi}

Materi yang diberikan kepada kelompok telah sesuai dengan rancangan yang telah dibuat. Proses intervensi pun berjalan dengan sesuai rencana. Partisipan selalu hadir dan kooperatif. Selama sesi intervensi, intervensi dilakukan selama dua jam disesuaikan dengan diskusi kelompok yang 
dilakukan. Para partisipan mampu bekerja sama dan mengikuti aturan kelompok yang telah dibuat. Walaupun, beberapa kali partisipan memotong pembicaraan karena ingin menceritakan dan menjelaskan keinginan mereka. Dalam sesi diskusi, para partisipan terlibat aktif, mereka saling bekerjasama dengan baik dan telah sesuai dengan yang diharapkan. Para partisipan juga merasa terbantu karena semakin belajar untuk mengontrol diri serta menghargai hasil karya temantemannya. Selama proses intervensi berlangsung, B dan L merupakan partisipan yang paling aktif berbicara dan mengingatkan ketika temannya melakukan pelanggaran seperti berbicara kasar. Namun, secara keseluruhan mereka mampu untuk menghargai dan bersemangat dalam bekerjasama serta mengikuti seluruh rangkaian terapi. Kemudian, R yang kurang begitu aktif dan sering mengeluh ketika menyelesaikan tugas, namun tetap kooperatif mengikuti seluruh rangkaian terapi. Sedangkan, $\mathrm{P}$ dan $\mathrm{N}$ merupakan partisipan yang paling sering bertengkar namun akhirnya dapat menahan diri untuk tidak bertengkar dalam waktu yang lama. Intervensi telah membantu partisipan dalam mengurangi kecenderungan agresi verbalnya.

\section{Saran}

Untuk peneliti selanjutnya direkomendasikan untuk menambah sesi terapi dengan kegiatan yang lebih menarik serta kreatif agar partisipan merasa lebih antusias dan bersemangat dalam mengikuti kegiatan dan partisipan dapat memperoleh kesempatan yang lebih banyak untuk melalui proses intervensi, sehingga hasil yang diperoleh dapat lebih signifikan. Selain itu ada baiknya jika peneliti selanjutnya dapat mengatur jadwal yang tepat dengan pihak lembaga terkait serta bekerjasama dengan orangtua partisipan, sehingga sesi terapi dapat berjalan sesuai dengan jadwal yang telah direncanakan. Namun yang terpenting untuk peneliti selanjutnya adalah memperhatikan ruangan yang digunakan untuk intervensi dengan mengusahakan menggunakan ruangan yang sesuai dengan kapasitasnya dan nyaman sehingga anak tidak merasa kepanasan. Ruangan yang kondusif adalah ruangan yang tidak terlalu banyak barang-barang di dalamnya sehingga anak dapat bergerak bebas ketika melakukan suatu aktivitas dan tertutup sehingga kesempatan anak-anak lain untuk melihat atau bahkan mengganggu terminimalisir sehingga tidak mengganggu konsentrasi partisipan kelompok dalam melakukan aktivitas.

\section{REFERENSI}

Buss, A.H \& Perry, M. 1992. The Aggression Questionnaire. Journal of Personality and Social Psychology. The American Psychological Association, Inc.

Djiwandono, S. (2005). Konseling dan terapi dengan anak dan orang tua. Jakarta: PT Grasindo. Hurlock. E. B. (1987). Perkembangan anak. Jakarta : Erlangga.

Kartono, K. (2007). Perkembangan psikologi anak. Jakarta: Erlangga.

Kristianto, A (2009). Perilaku Agresif Anak-anak Perkampungan Sosial Pingit Yayasan Sosial Soegijapranata. Skripsi. Yogyakarta: Universitas Sanata Dharma.

Landgarten, H.B. 1981. Clinical Art Therapy A Comprehensive Guide. New York : Bruner/Mazel publishers.

Landreth, Garry L. 2001. Innovations In Play Therapy. London : Taylor \& Francis Group

Malchiodi, C. (2003). Handbook of art therapy. London: Guilford Press.

Mulyana, Deddy, Ibrahim, Idi S. (1997). Bercinta dengan Televisi. Bandung: Remaja Rosda Karya.

Pohan, I. (1986). Masalah anak bermasalah. Jakarta: PT Midas Surya Gratinda.

Santoso, H. (2005). Disini matahariku terbit. Jakarta: PT Gramedia. 
Shechtman, Z., Freidman, Y., Kashti, Y \& Sharabany, R. 2009. Group Counseling to Enhance Adolescents Close Friendships. International Journal of Group Psychotherapy, 52, 4; 537 553

Wirawan. 2009. Evaluasi Kinerja Sumber Daya Manusia: Teori Aplikasi dan Penelitian. Jakarta: Salemba Empat. 